\title{
TRANSLATION OF THE RELATIONAL VALUES OF EUPHEMISTIC EXPRESSIONS INTO ENGLISH FROM INDONESIAN LITERARY WORK
}

\author{
Ahdi Riyono \\ Department of Language Education, Postgraduate Studies, Universitas Negeri Jakarta, Indonesia \\ E-mail: ahdariyono_pb13s3@mahasiswa.unj.ac.id \\ Emzir \\ Department of Language Education, Postgraduate Studies, Universitas Negeri Jakarta, Indonesia \\ E-mail: emzir@unj.ac.id \\ Ninuk Lustyantie \\ Department of Language Education, Postgraduate Studies, Universitas Negeri Jakarta, Indonesia \\ E-mail: ninuk.lustyantie@unj.ac.id
}

\begin{abstract}
APA Citation: Riyono, A., Emzir, \& Lustyantie, N. (2019). Translation of the relational values of euphemistic expressions into English from Indonesian literary work. English Review: Journal of English Education, 8(1), 121-128. doi: 10.25134/erjee.v8i1.2092.
\end{abstract}

Received: 21-09-2019

Accepted: 26-11-2019

Published: 01-12-2019

\begin{abstract}
This research is to describe the forms and translation techniques of Euphemism in the rendering of The Dancer novel by René TA Lysloff. The researcher used a qualitative method with a content analysis technique. The Data of research are in the forms of clauses containing expressions of Euphemism. The data source was taken from Ronggeng Dukuh Paruk (RDP) novel and its translation of the Dancer. The result showed that there were 35 data $(83.3 \%)$ of the Euphemism forms of translated into euphemisms, and only 7 data $(16,7 \%)$ of euphemisms were translated into other forms. The techniques used include single, duplet, and triplet techniques. The conclusions of the research showed that there were shifts in ideological forms and values of the translated novel.
\end{abstract}

Keywords: translation; euphemistic expressions; ronggeng dukuh paruk; the dancer.

\section{INTRODUCTION}

At present, translation research does not only focus on lexical or grammatical equivalences but also focuses on factors that can influence the translator to make decisions when having difficulties in the translation process. One of these factors is ideology. Hatim \& Mason (1997) say that some factors, for instance, politeness, power, and ideology have roles in the selection of decisions emerging from the smallest element of language to the largest element of language. The ideological term has two contradictory understandings. Positively, ideology is perceived as worldviews that state the values of certain social groups to defend, maintain and advance their interests, whereas negatively, ideology is viewed from false consciousness, namely a need to commit fraud by distorting people's understanding of reality.

In a discourse, ideology is usually manifested or coded in linguistic elements, including lexical, grammatical, and textual elements. In the lexical aspect, ideology can be realized in relational values related to euphemistic expressions. These expressions aim to refine the real reality. Euphemism is used to avoid something directly with educational goals. But it can also be misused to cover up the lack of political expression (Darma, 2009; Fairclough, 1989).

There have been several previous studies that were used as references in this study, including Mansourabadi and Karimnia (2012) This research had a purpose to reveal differences in ideology between Hoseini' s novel A Thousand Splendid Suns and the novel and two translations in Persian by Ganji and Soleimani, and Ghebrai. Fairclough maintained that ideology in discourse is encoded in the lexical, grammatical, and textual items and changes in these items indicate different ideologies. Hence, lexical choices of the sourcebook and the two translations were analyzed based on Fairclough's approach to investigating the differences of ideology between them. The results of chi-square showed that there were no ideological differences between the original text and its two translations. Furthermore, the translator selected similar 
vocabularies for representing the ideology of the source text author.

Another study is written by Anggraini \& Himmawati (2017) entitled "Translation Equivalence of Swearword in the Walking Dead Comic". This study by using the theory of Bell (1991) was to analyze how the equivalence of swearwords translation based on its translation technique proposed by Davoodi (2009). This research found that all of the techniques are used to translate swearword, they were censorship technique, substitution technique, taboo for taboo technique, and euphemism technique. The translation result also has a shift of form, the shift of meaning, and the theme.

The study of Shehab, Qodan, \& Hussein (2014) examines the role context plays in determining the translation strategies pursued by translators of Arabic euphemisms into English. Due to different cultural backgrounds, adherence to the employment of euphemism in a social context may differ in both Arabic and English. While some situations call for the use of euphemism in one culture, the other culture finds no point in using such euphemisms for such situations; preserving the original Arabic euphemisms when rendered into English, in this case, could lead to misunderstanding and may deprive the source language (SL) from a cultural trait. The study derives evidence from 11 Arabic euphemistic expressions taken from five literary masterpieces written by the Egyptian novelist and noble prize winner Najib Mahfouz, and it looks into the English translation of these euphemisms. The present study attempts to advance the proposition that Arabic euphemisms in their context exhibit fluctuating, unstable meaning, which emanates from various contextual factors such as speakers, addressees, shared knowledge and background information, and hence, these factors combined dictate on translators the chosen transference strategies.

Then the study of Meilasari, Nababan, \& Djatmika (2016) entitled Translation Analysis of Euphemism and dysphemism expressions found in online BBC News. This research is descriptive qualitative in nature with a single embedded case. The data of the research are all euphemism and dysphemism expressions found in $20 \mathrm{BBC}$ news texts and their translations. The data collecting method applied in this research are document analysis, questionnaire, and focus group discussion. While the data analysis technique used in Spradley's ethnographic method. Most of the Euphemism dan dysphemism expressions are translated by maintaining those expressions in the target text. English dysphemisms rendered into Indonesian ones are $50 \%$ data, and $25 \%$ data of euphemism expressions transferred into Indonesian euphemism. The established equivalence technique is the more translation techniques used.

Based on previous research conducted by researchers, there are some gaps or problems that can be examined more deeply than previous research. Some of the previous studies examined euphemism from political discourse, regional language, and stylistics in political and novel news discourses. However, the study of euphemism on the Indonesian novel and Its English in terms of Fairclough's ideological is more interesting than the previous studies. Because it explores a euphemism in the context of local culture. A novel is a work in which it uses beautiful language. In adult novels, there are often found refinement of words that have vulgar meanings and taboos that can affect the acceptability of a novel. Refinement also often occurs in translations of novels that are related to the existing culture. In this study, researchers chose the Ronggeng Dukuh Paruk novel (2012) and its translation (2012). Several things make researchers interested in examining the euphemism in the novel. First, the novel is a reflection of the author's ideology. Ahmad Tohari's novel RDP is famous for its portrayal and defense of the lives of small people, especially in rural areas.

Besides, the RDP novel has received many awards from literary lovers in Indonesia and internationally. Second, this novel has been published in various languages in the world, including in English. After reading the RDP text and the translation it was found that there were many euphemisms used to express certain meanings. Moreover, according to (Fairclough, 1989), the use of euphemism can be used to uncover the ideology of writers and translators. Therefore, this is where researchers are interested in researching more about the ideology that is reflected in the use of euphemism and the way it is translated. From the use of euphemism, the theory says that ideology is seen from the use of lexical choices, especially its euphemism and its translation, as well as the translation of euphemisms and their equivalence.

Then, this research explores the kinds of euphemistic expression forms rendered into English, and how to achieve correspondence as well as equivalence chosen by the translator. 
Euphemism term comes from the Greek word the meaning of Euphemizein is the use of words with appropriate senses or good-faith (Keraf, 2004). The euphemistic expression is an expression of language that softens the actual reality. According to Larson (1984, 1989), euphemism is a figure of speech that is similar to metonymy, namely the replacement of a word or phrase with another word or phrase. However, as Beekman and Callow (1974) cited by Larson ( 1984, 1989); Anita, Nababan, Santosa, \& Wibowo (2019) that euphemism used to avoid expressions that may offend people, who are not socially acceptable, or unpleasant. Correspondingly Keraf asserts that like the style, the language of euphemism is a reference in the form of expressions that do not offend or suggest something unpleasant (Keraf, 2004).

Also, Allan and Burridge (1991) define euphemism as alternatives to dispreferred expressions and is used to avoid possible loss of face. The dispreferred expression may be taboo, fearsome, distasteful, or for some other reason has too many negative connotations to felicitously execute a speaker's communicative intention on a given occasion.

The above definition, it should be noted, takes an explicit account of the face loss, the basic to euphemism. Concerning this point, Farghal (1995) cited by (Shehab, Qadan, \& Hussein, 2014) said that the face notion is the main factor to comprehend the speaker's meaning and subsequently the lexical correlates in his/her utterances. Hence, It is not only important in choosing our utterances, but also in understanding the meaning of these utterances.

With another language, the expression is euphemistically used to avoid anything directly with the goal of educational value. However, this euphemistic expression is often misused in political discourse to cover the shortfall expressions. It is also revealed by Wijana that euphemism usage of the word or other forms to avoid any form of restrictions or taboo in the language (Wijana \& Rohmadi 2008). All languages in the world have euphemistically expressions, especially in the realm of sexual activities, death and the supernatural (Larson, 1984, 1989), For example;

(1) Ayahnya sudah tak ada di tengah-tengah mereka (= mati)

Her father was not there in the middle of them (= death).

(2) Pikiran sehatnya semakin merosot akhirakhir ini (= gila).
His senses slump lately (= mad).

Jews, for example, uses the word of surga (heaven) to avoid using the name of Allah or God directly. Most languages have a way to say mati/ die, without using words that have a primary meaning of death. English uses the word pass away, Indonesian uses the word death, passed away, back to the bosom of God, etc., using the Hebrew language to the father gone, gone to sleep or is sleeping (Larson, 1984, 1989).

The speaker's choice for euphemism is seemingly meant to soften their face, that of the audience or some third party by softening negative connotations or including positive ones, as Allan and Burridge (1991) indicate. It should be emphasized that the use of euphemistic language reveals much about the speaker relations among speakers, addressees or some third parties. This may be true mainly because the speaker's choice for euphemism is deliberate. For instance, a speaker may intentionally resort to using emotive euphemistic expressions to highlight the intended meaning to be conveyed through codes, since euphemism is generally associated with positive emotiveness.

In the rendering of euphemism, the translator must also choose a phrase that in the form of euphemism is also comparable (Larson, 1984, 1989; Suryawinata \& Hariyanto, 2003), Euphemism in this SL can be a literal translation of euphemism of SL if it has a figurative meaning closeness. Only if he had any, euphemisms can be replaced with words that have the same literal meaning. The following are examples of translating sentences that use euphemisms (Suryawinata \& Hariyanto, 2003);

BS: Ibunya telah berpulang tiga tahun yang lalu.

BT: His mother passed away three years ago.

(TL changed to euphemism.).

BS: Putra Pak Bupati terganggu jiwanya

BT: The Regent's son is mentally imbalanced.

(Euphemism BS euphemism replaced with the equivalent of BT).

BS: He is a little slow.

BT: ia sedikit lambat (Euphemism BS translated literally to BT.).

BS: She is not feeling well.

BT: Ia sedikit tak enak badan.

The linguists of the Summer Institute of Linguistics provides an important record if translated phrase euphemism (Barnwell, 1980);

a) Keep alert to Recognize when a Euphemism is being used in the source text. If the source 
language is not your mother tongue, make sure that you have understood the actual meaning, as distinct from the surface meaning of the words.

b) Be sensitive to the cultural conventions of the receptor culture.

Sometimes euphemism in the original text (ST) can be transferred directly into the target language. Sometimes euphemism in ST must be translated into the target language euphemism (TT), but different in the forms despite having a meaning in line with TT. Sometimes something that is referred to by ST may be translated into the TT euphemism to avoid sensitive phrases in the reader's culture. In the same expression Larson (1984) explains that euphemism will often need to be translated by a comparable euphemism in the receptor language. The important thing is for the translator to recognize the euphemism nature of the source language expression and then translate with an appropriate and acceptable expression of the receptor language whether euphemistic or not.

\section{METHOD}

This research focuses on describing the forms and techniques of translation of Euphemism in the Translation of The Dancer novel by René TA Lysloff. This study used qualitative methods with the content analysis technique. The Data in this research was taken from clauses containing euphemistic expressions of The Dancer, an English version (Tohari, 2012b), and the original one, Ronggeng Dukuh Paruk (RDP) (Tohari, 2012a). The note-taking technique was employed in collecting the data, in which firstly, they were read several times. Secondly, the euphemistic expressions were noted and finally classified into types of translations.

\section{RESULTS AND DISCUSSION}

The use of euphemisms in the literary text of the Ronggeng Dukuh Paruk novel is closely related to the ideology adopted by the text writer, namely Ahmad Tohari and the translator, Lysloff. Tohari wants to show his appreciation for humanity universally by replacing taboo, rude, or disrespectful words with a form of euphemism. However, in translating the text into English, sometimes, Lysloff is contrary to the ideology of the source text writer. This is evidenced by the existence of several shifts in number and form of euphemism expressions in the TT. These indicated that there are some ideological shifts in the TT.

Table 1 explains that the translation of euphemisms into euphemisms in English is 35 data $(83.3 \%)$. This shows that there are some forms of euphemism in source languages that are not rendered into euphemism in the target text (TT). The forms consist of 7 data (16.7\%). The existence of these differences indicates that there is a shift in the different forms of ST. The following is a discussion of each translation form of euphemism.

Table 1. Relational values of euphemistic expressions in RDP and translated novel of the dancer

\begin{tabular}{ccc}
\hline $\begin{array}{c}\text { Relational Values of } \\
\text { Euphemistic Expressions }\end{array}$ & $\begin{array}{c}\text { Frequency } \\
\sum\end{array}$ & $\begin{array}{c}\text { Percentage } \\
\text { \% }\end{array}$ \\
\hline Euphemism->Euphemism & 35 & $83,3 \%$ \\
Euphemism-> Non-Euphemism & 7 & $16,7 \%$ \\
Total & 42 & $100 \%$ \\
\hline
\end{tabular}

\section{Translating euphemism into euphemism} [Sample 1]

ST : Tanpa terganggu oleh jerit dan tangis, $\underline{\text { maut }}$ terus menjemput orang-orang Dukuh Paruk. (p. 29).

TT : Undeterred by screams and mourning, death called upon the people of Paruk. (p.27).

The clause 'maut terus menjemput orangorang Dukuh Paruk in the [Sample1] of ST is a form of expression of euphemism. The verb of menjemput with the subject of maut, a form of smoothing meaning of the death continuing to fall due to the eating of tempe bongkrek. It showed that the association of menjemput has a positive meaning. The word of menjemput on [Data 1] was translated into English by the word called upon. In the Cambridge Advanced Learner's Dictionary, the word call upon is to visit someone, especially to sell them something. This implies that the word call upon also associated with something positive. Thus, the use of the word call upon in the TT inline in the form of a menjemput word in the expression context. It is in conjunction with what Larson maintains that the translator must also choose a phrase that in the form of euphemism is also comparable 
ENGLISH REVIEW: Journal of English Education Volume 8, Issue 1, December 2019
p-ISSN 2301-7554, e-ISSN 2541-3643

https://journal.uniku.ac.id/index.php/ERJEE
(Larson, 1984, 1989; Suryawinata \& Hariyanto, 2003).

[sample 2]

ST : Dalam tempat tidur ini kelak Srintil akan diwisuda oleh laki-laki yang memenangkan sayembara (P. 52).

TT : In this bed, Srintil would be deflowered by the man who won the contest. (P.52).

The word of diwisuda contained in the [sample 2] of ST is derived from the root word wisuda. The lexical meaning of the wisuda, according to Big Indonesian Dictionary (Kamus Besar Bahasa Indonesia) is the dedication or inauguration with a solemn ceremony. In the context of the sentence in [Data 2] The word of wisuda is a kind of euphemism of those who win the virginity contest to have a sexual intercourse with the candidate of ronggeng dancer, Srintil, in the eve of Bukak-Klambu. While the words to diwisuda in ST translated by Lysloff into English being deflowered. The word deflowered in Longman Dictionary of english Language and Culture is defined as to have sex with a woman who has not had sex before. Thus, the translation of the word form, deflowered with the word of diwisuda has been equivalence because it was the same form of a euphemism. It is also in line with Larson (1984), and Barnwell (1980).

\section{Translating euphemism into non-euphemism} [Sample 3]

ST : Di sana, di dalam kurung kelambu yang tampak dari tempatku berdiri, akan terjadi pemusnahan mustika yang selama ini kuhargai (p. 53).

TT : There, inside the cage of mosquito netting, which was visible from where I Stood, the destruction of something that I'd always valued, would take place. (P.53).

The word of mustika on [sample 3] in the ST is a euphemism form of keperwanan. The use of Perusahaan and mustika words showed that Tohari appreciated women. The word of pemusnahan in the context of the [sample 3] showed that bukak-klambu, an event that must be endured by Srintil as the requirement to become a ronggeng is a tragedy for a woman's self-esteem in general. As said by Fairclough that text writers often use strategies to avoid values of expressive words for relationship reasons. Euphemism is a form of words used to replace other words, with the aim of making it more convenient and more known as a remedy effort to avoid negative values (Fairclough, 1989), As for the target text (TT), the translator is difficult to find the equivalent word of mustika in ST such as context, so he used a form of the clause to describe the purpose of the mustika word, $\underline{i e}$ something that I'd always valued (sesuatu yang selalu saya hargai). In terms of form, the word is not equivalent, on the other hands, it's equivalent in terms of it's meaning. The translation clause actually was not a euphemism, but it's the usual description. It has been in connection with the theory of Barnwell (1990). He said that sometimes, euphemism of ST could be rendered onto the TT, different at the form but similar with the meaning.

[Sample 4]

ST : Srintil hanya ingin disebut sebagai perempuan utuh. Dia sungguh-sungguh ingin melahirkan anakku dari rahimnya. (p. 105).

TT : but just as a woman, She truly wished to have my child in her womb. (p. 110).

The phrase perempuan utuh on the [sample 4] of ST has a connotation meaning, ie women who have a legitimate husband and have children. A Javanese woman is not considered as a true woman when it is time for her to get married and to have children, she was still alone, and no man who proposed to her. The phrase perempuan utuh is a form of euphemism. Namely, the smoothing to the meaning of the woman who has a husband. As for the phrase of perempuan utuh which was translated into English by Lysloff just as a woman is not the connotation, but denotation. It is also in line with Larson's theory (1984).

\section{Translation method and technique in a translated novel of The Dancer}

The total data containing euphemistic expressions is 42 data $(\mathrm{N}=42)$. Referring to the results of the analysis, it was concluded that euphemistic expressions were translated using a single, duplet, and triplet translation techniques.

The single translation technique used by the translator is a literal technique, the total of data is $15(36 \%)$, descriptive equivalent techniques of 2 data (5\%), modulation techniques of 8 data (19\%), transference techniques of 2 data (5\%), naturalization techniques of data (2\%), functional equivalent techniques of 2 data (5\%), reduction techniques of 1 data (2\%), and cultural equivalent techniques of 2 data (5\%). Then duplet translation techniques are Literal + reduction techniques 4 data $(10 \%)$, Literal techniques + modulation 1 data (2\%), Naturalization + generalization of 1 data (2\%), and Literal techniques + additions 1 data $(2 \%)$. Then the triplet translation technique is Transference + Literal + addition of 1 data (2\%), and the 
technique of Transposition + literal + add 1 data $(2 \%)$. Of the many singles, duplet, and triplet translation techniques used, the translator tends to be more dominant using translation techniques that are oriented to the target language (TL) with a percentage of $78 \%$. The dominant method of translation used is communicative with a percentage of $78 \%$. Thus, it can be concluded that the translator is more oriented to the domestication translation ideology.

Table 2. Translation methods and techniques frequency in The Dancer novel

\begin{tabular}{|c|c|c|c|c|c|}
\hline & Single & Literal & & 15 & $36 \%$ \\
\hline & & Descriptive Eq & iivalence & 2 & $5 \%$ \\
\hline & & Modulation & & 8 & $19 \%$ \\
\hline & & Transference & & 2 & $5 \%$ \\
\hline & & Naturalization & & 1 & $2 \%$ \\
\hline & & Functional Equi & valence & 2 & $5 \%$ \\
\hline & Technique & Reductions & & 1 & $2 \%$ \\
\hline & & Cultural Equiva & lence & 2 & $5 \%$ \\
\hline & & Literal + reducti & & 4 & $10 \%$ \\
\hline & Duplet & Literal + modul & ation & 1 & $2 \%$ \\
\hline eunhemistic expressions & & Naturalization + & generalization & 1 & $2 \%$ \\
\hline$(\mathrm{N}=42)$ & & Literal + additio & & 1 & $2 \%$ \\
\hline & & Transference + & Literal + addition & 1 & $2 \%$ \\
\hline & Triplet & Literal transposi & tion ++ addition & 1 & $2 \%$ \\
\hline & & Literal & & 17 & $40 \%$ \\
\hline & Method & Semantics & & 3 & $7 \%$ \\
\hline & & Communicative & & 21 & $50 \%$ \\
\hline & & Idiomatic & & 1 & $2 \%$ \\
\hline & & Foreignization & Literal & 17 & $40 \%$ \\
\hline & Ideology & & Semantics & 3 & $7 \%$ \\
\hline & & domestication & Communicative & 21 & $50 \%$ \\
\hline & & & Idiomatic & 1 & $2 \%$ \\
\hline
\end{tabular}

\section{Single techniques \\ Literal}

Literal translation is often demostrated as interliniear translation, with the TL immediately below the SL words. The SL word-order is preserved and the words translated singly by their most common meanings, out of context. In another word, is can be said that literal translation is a word for word one to express the meaning of a single word (Moentaha, 2008; Newmark, 1988; Suryawinata \& Hariyanto, 2003). The single technique used by the translator reaches 15 data $(36 \%)$. So that , the most dominant technique of all the techniques used is literal translation. This also leads to the conclusion that $t$ the semantic method is quite widely used as well. If it is summed up overall it reaches $47 \%$, and this is a significant number showing that the ideology of foreignization is quite widely used by translators. [Sample 1]

TS : Dalam tempat tidur ini kelak Srintil akan diwisuda oleh laki-laki yang memenangkan sayembara. (p. 52).

TT : In this bed, Srintil would be deflowered by the man who won the contest. (p. 52).
The word for diwisuda in the ST sample was a form of euphemism from sexuality activity when Srintil underwent the open-door ceremony as a condition to become a ronggeng. The word of diwisuda translated by Lysloff becomes deflowered. The word of deflowered is also classified as the word euphemism in the TT. In terms of denotation, the word of deflower has the meaning of picking flowers. Whereas according to the definition of web, deflower is the act of taking the virginity of a girl (U-Dictionary). Virginity is the person who has never engaged in sexual intercourse (someone who has never had sexual relations). The translation of euphemisms into euphemism is in line with those suggested by $\operatorname{Larson}(1984,1989)$ that the translation of the euphemism from the source language usually must be translated with euphemism in the target text (TT) as well. Thus, the translation using the literal technique is commensurate with the meaning referred to in TS. This technique finding differs from those of Meilasari's Finding that there was no literal technique employed by the translator (Meilasari et al., 2016). This shows that not all euphemism could be transfered into euphemism literally in the TT. 
ENGLISH REVIEW: Journal of English Education Volume 8, Issue 1, December 2019
p-ISSN 2301-7554, e-ISSN 2541-3643

https://journal.uniku.ac.id/index.php/ERJEE

\section{Modulation technique}

Modulation is a translation technique by looking for an equivalence in TT by changing the perspectives that have the same meaning (Machali, 2000; Newmark, 1988; Suryawinata \& Hariyanto, 2003; Venuti, 2000). The modulation technique is the second technique applied by the translator occurring for 8 times of the amount of data (19\%). Meanwhile, the dominant method employed by the translator is the communicative method. There are 21 data or (50\%) showing the use of communicative one in the translation of euphemistic expressions. Accordingly, the ideological orientation of the translator tends to use domestication.

[Sample 2]

ST : Rasanya, sebagai anak laki-laki tak ada yang salah pada tubuhku. (p. 67).

TT : I believed that I was a normally functioning male. (p. 67).

The expression of euphemism on ST sample tak ada yang salah pada tubuhku translated into TT with the expression of euphemism as well, namely the normally functioning male. The source text writer (TS) uses the point of view that there is nothing wrong as a man arises passion when Rasus sees Srintil naked (external viewpoint). While the translator uses the viewpoint as a normal man Rasus naturally feels a tremendous lust when he sees Srintil naked (internal perspective). This shows that the difference in semantic viewpoint between TS and TT does not cause differences in meaning or message between the two texts. Translation with a different perspective in translation is called modulation (Machali, 2000; Newmark, 1988; Suryawinata \& Hariyanto, 2003; Venuti, 2000). Translation with these modulation techniques has been in line with what was suggested by Barnwell (1980) in the book Introduction to Semantics and Translation from the Summer Institution of Linguistics and also the same as the research's result of Meilasari et al. (2016), and Arifin et al. (2017).

\section{Couplets technique}

Couplets are translation techniques using two different techniques in translating a speech or a sentence (Newmark, 1988; Ordudari, 2013). There are four duplet techniques applied by the translator, but the most widely used is the duplet of literal + reduction technique, which is 4 data $(10 \%)$. The dominant method applied is the communicative method with a tendency to side with the target text reader or ideologically translation tends to domestication. The following is an example of the dominant duplet method;

Literal + reduction

[Sample 4]

TS : di sana, di balik pusar, aku pernah bersemayam selama Sembilan bulan dalam rahimnya. (h.67)

TT : I had resided for nine months in her womb (p.67).

The euphemism in the ST is there, di balik pusar is translated into in her womb using the direct form in the TT. The translation techniques used by translators are literal and reduction techniques because the expression of di balik pusar is literally translated into non euphemistic form.

\section{Triplet technique}

Triplet is a way that translators do to combine three different techniques in translating speech or sentences (Ordudari, 2013). There are two triplet techniques used by translators in translating euphemistic expressions, namely transference + literal + addition, and transposition + literal + addition. The following is an example of one of these techniques;

[Sample 5]

TS : Di sana, di Dukuh Paruk, aku juga tahu ada obat bagi perempuan-perempuan mandul. Obat itu bernama lingga; kependekan dua kata yang berarti penis tetangga (h. 86).

TT : I also knew of treatment for childless women which was common in the village. The treatment was called lingga: a combination of the abbreviation of two Javanese words "neighbor's penis. (p.88).

The word acronym lingga is a short form of euphemism of two words, namely the neighboring penis. The word of lingga has ideological content, which is a symbol of virility, strength, and fertility. In Javanese culture, lingga is always combined with the word of yoni, a symbol of femininity, motherland. For married women who are barren in the Dukuh of Paruk, it is not as a taboo if they have an affair with a neighbor so they have children because that's the medicine that works in overcoming infertility according to their ideology. Dukuh Paruk people have a loose norm because they are not bound by any religious norms and values. Their belief was only focused on the spirit of their ancestors, namely Ki Secamenggala. The word of lingga is translated by the transference technique into lingga in the TT. Then an additional description of two words, kependekan dua kata yang berarti penis tetangga which means the neighbor's penis, is translated by a literal technique and the 
technique of addition with the word of the combination becomes a combination of the abbreviation of two Javanese words "neighbor's penis.

\section{CONCLUSION}

This paper has examined kinds of euphemistic expression forms and the translation techniques used to render the euphemism in the ST into the TT pursued by the translator. From the discussion on the research findings above, it can be concluded that there are 42 data of euphemism used in ST. The relational values of euphemistic expressions which are translated into TT with the same form of euphemism are 35 data $(83,3 \%)$, and only $7(16,7 \%)$ data translated into noneuphemism forms. This shows that there are some shifts in the forms of euphemism in the TT. the shifts must be taken by the translator since there are socio-cultural differences in the TT. this is in line with Larson (1984) maintains that all human codes have terms of expressing euphemistic utterances that substitute for certain words, especially in the area of sex, death, and the supernatural. Euphemism often needs to be rendered by a comparable euphemism in the receptor language.

The study reveals that the relational values of euphemistic expressions were translated into TT using single, duplet and triplet techniques of translation. The most dominant of a single technique used is literal technique, and the most dominant of duplet technique is the literal + reduction. On the other hand, there are two kinds of triplet techniques, namely Transference + Literal + addition and Literal transposition taddition.

The use of translation methods oriented to the source and target languages by translators is almost balanced. Because of the overall method used, the source language-oriented method is around $47 \%$ and the opposite is around 52\%. Thus, in transferring the source text (TT) into the target one, the translator remains oriented towards the target language reader, so there are several cultural expressions of ST that are translated into TT that used source-oriented techniques and there are also some which are oriented to the target language. From those discussions, it could be concluded that the translator, in this case, René T.A Lysloff tried to have a balance in the translation of literary texts, especially Ahmad's novel of RDP.

\section{REFERENCES}

Allan, K., \& Burridge, K. (1991). Euphemism and dysphemism: Language used as shield and wapon. New York: Oxford University Press.

Anita, Nababan, M. R., Santosa, R., \& Wibowo, A. H. (2019). The Indonesian translation of English sexual euphemistic expressions in desperate duchesses by Eloisa James. ELLiC Proceedings, 3, 368-373.

Arifin, D. Z., Wiratno, T., Linguistik, M., Pascasarjana, P., Sebelas, U., \& Maret, U. S. (2017). Analisis terjemahan eufemisme organ dan aktifitas seksual dalam novel fifty shades of grey. Prasasti: Journal of Linguistics, 2(2), 190204.

Barnwell, K. G. L. (1980). Introduction to semantics and translation. Horsleys Green: Summer Institute of Linguistics.

Fairclough, N. (1989). Language and power ( $1^{\text {st }}$ ed.). London and New York: Longman.

Hatim, B., \& Mason, I. (1997). The translator as comunicator. London and New York: Routledge.

Keraf, G. (2004). Diksi dan gaya bahasa. Jakarta: PT. Gramedia Pustaka Utama.

Larson, M. L. (1984). Meaning-based translation: A guide to cross-language equivalence ( $1^{\text {st }} \mathrm{ed}$.). Boston: University Press of America.

Larson, M. L. (1989). Penerjemahan berdasarkan makna: Pedoman untuk pemadanan antarbahasa. Jakarta: Penerbit Arcan.

Machali, R. (2000). Pedoman bagi penerjemah. Jakarta: PT. Grasindo.

Meilasari, P., Nababan, M. R., \& Djatmika. (2016). Analisis terjemahan ungkapan eufemisme dan disfemisme pada teks berita online BBC. Prasasti Journal of Linguistics, 1(2), 336-358.

Moentaha, S. (2008). Bahasa dan terjemahan ( $2^{\text {nd }}$ ed.). Jakarta: Kesaint Blanc.

Newmark, P. (1988). A textbook of translation $\left(1^{\text {st }}\right.$ ed.). New York: Prentice Hall.

Ordudari, M. (2013). Translation procedures, strategies and methods. Theory and Practice in Language Studies, 3(5), 781-789.

Shehab, E., Qadan, A., \& Hussein, M. (2014). Translating contextualized Arabic euphemisms into English: Socio-cultural perspective. CrossCultural Communication, 10(5), 189-198. doi: $10.3968 / 4546$.

Suryawinata, Z., \& Hariyanto, S. (2003). Translation bahasan teori \& penuntun praktis menerjemahkan. Yogyakarta: Penerbit Kanisius.

Tohari, A. (2012a). Ronggeng dukuh paruk. Jakarta: PT. Gramedia Pustaka Utama.

Tohari, A. (2012b). The dancer. Jakarta: Yayasan Lontar.

Venuti, L. (2000). The translation studies reader $\left(1^{\text {st }}\right.$ ed.). London: Routledge.

Wijana, I. D. P., \& Rohmadi, M. (2008). Semantik teori dan analisis. Surakarta: Yuma Pustaka. 